\title{
Omni-Interaction Strategy to Create Holistic Omnchannel Consumer Experience
}

\author{
$1^{\text {st }}$ Djohan Gunawan ${ }^{1}, 2^{\text {nd }}$ Tirta Nugraha Mursitama ${ }^{2}, 3^{\text {rd }}$ Amalia E. Maulana $^{3}, 4^{\text {th }}$ Mohammad \\ Hamsal $^{4}$ \\ \{djohan gh@yahoo.com $\underline{1}$, tmursitama@ binus.edu $^{2}$, amalia@etnomark.com $^{3}, \underline{\text { mhamsal@ } @ \text { binus.edu }}^{4}$ \}
}

\author{
Student of BINUS Business School - Doctor of Research in Management Palmerah, Jakarta, Indonesia ${ }^{1}$ \\ Vice Rector Research and Technology Transfer, Bina Nusantara University, Palmerah, Jakarta, \\ Indonesia $^{2}$ \\ Lecturer of Magister Management Bina Nusantara University Palmerah, Jakarta, Indonesia ${ }^{3}$ \\ Lecturer of Doctor of Research in Management, Bina Nusantara University Palmerah, Jakarta, \\ Indonesia ${ }^{4}$
}

\begin{abstract}
Technology changes are impacted to all aspect of our life. In marketing called this period as the era of Marketing 4.0, which is a marketing approach that combines online, and offline interaction. This changes transformed the retailing landscape from offline become online and now online offline or omni-channel with click and mortar model. The strategy of omnichannel can have a interaction effect on retail, where a consumer's experience is properly enhanced through the simultaneous use of all available distribution channels as well as through perceived informativeness via online media, affordable via online at portable devices, and accessibility which make the experience unique and prompt consumers to shop comfortably anytime, anywhere. This paper aims to exploring the factors that have online and /or offline or Omni-interaction during the shopping for Omni-experience. The research was tested with a sample of data collected from a survey of omni-channel consumer. The finding indicate that the key determinants of omni-channel interaction has a significant impact on shopping experience mediating by perceived informativeness, affordable, and accessibility. The results contribute to the literature by providing a description of adoption omni-channel required understands consumers and their experiences, create comprehensive process of omni-channel retailing that makes it easy for consumers and retailer.
\end{abstract}

Keywords: omni-channel, consumer, retail, experience, interaction, perceived informativeness, affordable, and accessibility

\section{Introduction}

Technology changes are fueling the shift. This era is known as the era of Marketing 4.0, which is a marketing approach that combines online, and offline interaction (Kotler et al., 2016). The digital and physical worlds are blending on the consumer or the retail perspective (Rigby, 2011) allowing them to search for products and shop comfortably anytime, anywhere (Egol et al., 2012). Aubrey et al. (2012) state that technology has changed consumer attitudes and behaviors, arise from the notion of click and mortar, combine technology with traditional physical retailing, in order to enhance the value of the shopping experience (Otto et al., 2000; Burke, 2002).

The increasing diffusion and adoption of alternative business-to-consumer retail channels through both traditional and innovative retail settings has transformed retail practices and 
consumers' shopping processes. The new model of retail is omni-channel (Carvalho et al., 2014), achieves optimal effectiveness by combining offline marketing with offline marketing (Laudon et al., 2015), provide an easy process for consumers and sellers (Lazaris et al., 2014; McCormick et al, 2014; Rigby, 2011; Rigby, 2014).

Omni-channel represents the future of retail, and they have grown up in a world that enables both purchasing and servicing to be done instantaneously and digitally through any channel. Retailers understand that a strong omni-channel strategy can increase overall sales by giving consumers additional ways to gather information, make purchases, and receive products (Marshall et al., 2017). This required Omni-Interaction to make the purchase process on several channels that are integrated with consumers (Angel, 2014). This evolving perspective is good news, in that omni-channel servicing can pay dividends in the form of stronger consumer engagement, increased process efficiency and even lower costs.

The most interesting journal about Omni-channel was published (Brynjolfsson et al., 2013), dealing with Omni-channel concepts and strategies. This strategy can have a synergistic effect on retail, where a consumer's experience is properly enhanced through the simultaneous use of all available distribution channels (Gerritsen et al., 2014; Chopra, 2016) as well as through social media, applications for portable devices, which make the experience unique and prompt consumers to buy (Verhoef et al., 2015). The dominant characteristic of the omni-channel is that the strategy is centered on the consumer and the shopping experience, with a view to offering the shopper a holistic experience (Gupta et al., 2004) and the experience is seamless regardless of which channels the consumer uses (Herhausen et al., 2015).

\subsection{Omni-Interaction}

Today, the capability of internet access to simultaneous use of several consumer-store interaction channels through online access with the physical retail store. Omni-channel increases the emphasis on interactions between channels and brands, how these interactions work, integrating consumer, brand, and retail channels (Neslin et al., 2014). Interactions are used smoothly and alternately during the search, purchase, and post-purchase process (Verhoef et al., 2015).

Omni-Interaction is the ability to make the purchase process on several channels that are integrated with omni-channel consumers (Angel, 2014) and gives consumers many choices for purchasing activities (Fernie et al., 2015). The challenge is in integration between channels. Consumers expect a consistent, uniform, and integrated service or experience, regardless of the channel they use; they are willing to move seamlessly between channels depending on their preferences, their current situation, the time of day, or the product category (Cook, 2014; Piotrowicz et al., 2014).

To understand retailing and consumer experiences, consumers attempt to achieve some goal by purchasing and using a particular product (Ratneshwar et al., 2000), they place great value on the integration, thus a successfully implemented omni-channel strategy with a complete integration of all the channels has the potential to enhance greatly the consumer shopping experience (Herhausen et al., 2015).

Omni-channel must provide a superior shopping experience that is consistent and easy across all channels (Gorsch, 2002; Guptaet et al., 2004), combining online with offline marketing (Laudon et al., 2015) and gives consumers more choices to make purchases (Fernie et al., 2015). Much research has begun to refer to omni-channel retailing as a process that makes it easy for consumers and retailer (Lazaris et al., 2014; McCormick et al., 2014; Rigby, 
2011; Rigby, 2014; Carvalho et al., 2014), understands consumers and their experiences (Puccinelli et al, 2009).

\subsection{Perceived Informativeness}

Technological provide maximum interaction of experiences and thoughts of consumers through advertisements in online marketing (Ira et al., 2015). The era of passive consumers has ended (Yoran, 2008), technology changes the attitudes and behavior of consumers by giving various choices and authority to consumers (Aubrey et al., 2012).

The benefits of using online marketing will positively influence consumer attitudes and intentions (Lee, 2009). Dual-process theory / dual-process theory introduced by Deutsch and Gerrard (1955) about the influence of information and normative influence or often called perceived informativeness. Information influence is based on information content, source and recipient of information. Normative influence reflects the impact of social aggregation mechanisms available in the community or consumer groups.

Online marketing offers potential opportunities through speed and accuracy and also create challenges for creating integrated digital marketing (Rajeev et al., 2016; Karen et al., 1987; Yorgo, 1990). Advances in social media have caused many consumers to communicate online through Facebook, Twitter, blogs, and other online channels (Jonah et al., 2013; Schiffnan et al., 2015). Online product reviews are increasingly popular that consumers use to research products before they make a purchase (Bob, 2010). Word of mouth (WOM) communication has a significant impact on consumer purchasing decisions (Silverman, 2011). WOM does not involve the company or marketing (Blackwell et al., 2012), WOM is a communication of consumer satisfaction (Schiffman et al., 2015) and also social recommendations (Lin et al., 2013). The development of the Internet is changing online word of mouth communication called electronic WOM or e-WOM (Goldsmith et al., 2006; Schiffnan et al., 2015; Brown et al., 2009; Man et al., 2009; Smith, 2012). Based on Perceived Informativeness as a mediating variable for exogenous variable Omni-interaction and endogenous variable Omni-experience, the following hypothesis was thus proposed:

\section{H-1: Omni-interaction positively influence Perceived Informativeness}

\subsection{Affordable}

Technology provides consumers the opportunity to be able to choose the best deals and also the opportunity for consumers to engage in price comparisons (Brown et al., 2002; Zettelmeyer et al., 2006). With many choices and easy access to information, consumers in making decisions will become more complex and more important than ever before (Sam et al., 2015).

Affordable is the consumer's interaction to get the best product value by making comparisons from the point of view of the price and value of the product before making a purchase decision (Rayport et al., 2003; Mohammed et al., 2003). Dijk et al., (2005), found consumers actively assess the acquired information from several channels in order to obtain the best deal offered by the channel that suits them best at that moment. In order to act upon consumers' feelings, enhance their experience, and influence their decisions (Soars, 2009), some aspect need to consider for consumer point of view. Quality is referring to the extent to which qualification considerations play a central role in consumer decision (Steenkamp, 1989; Steenkamp et al., 2015). Price is the degree to which consumers focus on paying low prices (Lichtenstein et al., 1995). And the decision changes due to a comparison of quality and price with a tendency to respond to purchase offers where prices positively influence purchase evaluations (Lichtenstein et al., 1995). Affordable is a mediating variable for exogenous 
variable Omni-interaction and endogenous variable Omni-experience, the following hypothesis was proposed:

\section{H-2: Omni-interaction positively influence Affordable}

\subsection{Accessibility}

Consumers are connected to get access to information and buy anything, anywhere, anytime (Piotrowicz, 2014). Ease of access is the interaction of consumers to purchase or take products (Emma et al., 2016) also shows that consumers like to use various channels in the buying process, including access to purchase or take products (Fernie et al., 2015).

Saini et al. (2016) expand this finding to show that the advantages of organizing goods, the size and also the relationship with the seller, will make consumers to keep shopping at the same store (Ailawadi et al., 2001), and their tendency to keep shopping at the same store (Ailawadi et al., 2001; Toufaily et al., 2013), they are more oriented towards making purchases more often and more impulsively (Lissitsa et al., 2016). Accessibility is a mediating variable for exogenous variable Omni-interaction and endogenous variable Omni-experience, in keeping with the literature we proposed the following hypothesis:

\section{H-3: Omni-interaction positively influence Accessibility}

\subsection{Omni-Experience}

The goal of implementing omni-channel retailing is to create a seamless consumer experience by combining the benefits of both the online and offline (Rigby, 2011; Frazer et al., 2014). Online shopping allows consumers to meditate and reflect, in a relaxing way, about their purchases in the comfort of their own places (Zhang et al., 2010). The approach to the traditional offline channels is for expert advice; if consumer loves the touch-and-feel shopping as well as they want to save time as far as delivery (Kollmann et al., 2012). In order to meet consumers' needs and fully enhance their unique experiences and enjoyment, retailers change or renew their range of products, rethink or restructure the interior of the store and develop innovations for individual and corporate buyers (Dabija et al., 2016). In addition to innovation, an equally important role is played by the customization or individualization, at maximum level, where possible, of a retailer's products and services (Mochon et al., 2012; Siobhan et al., 2015).

Understanding and paying effort to create a omni-channel experience is not an option, but a necessity (Winter, 2012). Consumer not only saves a lot of time, but also optimizes the shopping experience, the utility of the purchased items, shortens the trip from one store to another, increases shopping enjoyment and thus increases satisfaction with the retailer and the application used (Yee et al., 2015). Therefore, consumers should feel satisfied with their experiences, since having a positive experience will lead to a positive predisposition purchase (Küster et al., 2016) and influence the intention to buy (Flor et al, 2017).

Omni-channel provides for a synergistic of the many available channels and consumer touch points so that the experience of clients through multiple channels is optimized (Herhausen et al., 2015). Verhoef et al. (2009) explicitly define consumer experience in a retailing as a multi dimensional construct is holistic in nature and involves the consumer's cognitive, affective, emotional, social, and physical responses to the retailer. Peter et al., (2010) describes consumer behavior involving thoughts and feelings experienced and actions taken in the buying and consumption process. Further research by Oliver (1997), Oliver (1999), Da Silvaet al. (2006), Carvalho et al. (2014), Garaus et al. (2015), Agnieszka (2017) and Juan (2017), found that the perceived benefits of using online services will positively influence consumer attitudes and intentions, which are based on cognitive, affective and 
conative, that are the basis from the theory of consumer attitudes (Fishbein et al., 1975). The following research hypothesis was thus formulated:

H-4: Perceived Informativeness positively influence Omni-Experience

H-5: Affordable positively influence Omni-Experience

H-6: Accessibility positively influence Omni-Experience

Based on the above information and hypothesis, this paper aims to exploring the factors that have online and /or offline or Omni-interaction during the shopping for Omni-experience mediating by Perceived Informativeness, Affordable and Accessibility. Novelty of this research is that Omni-interaction with ability to make the purchase process on several channels that are integrated with omni-channel consumers.

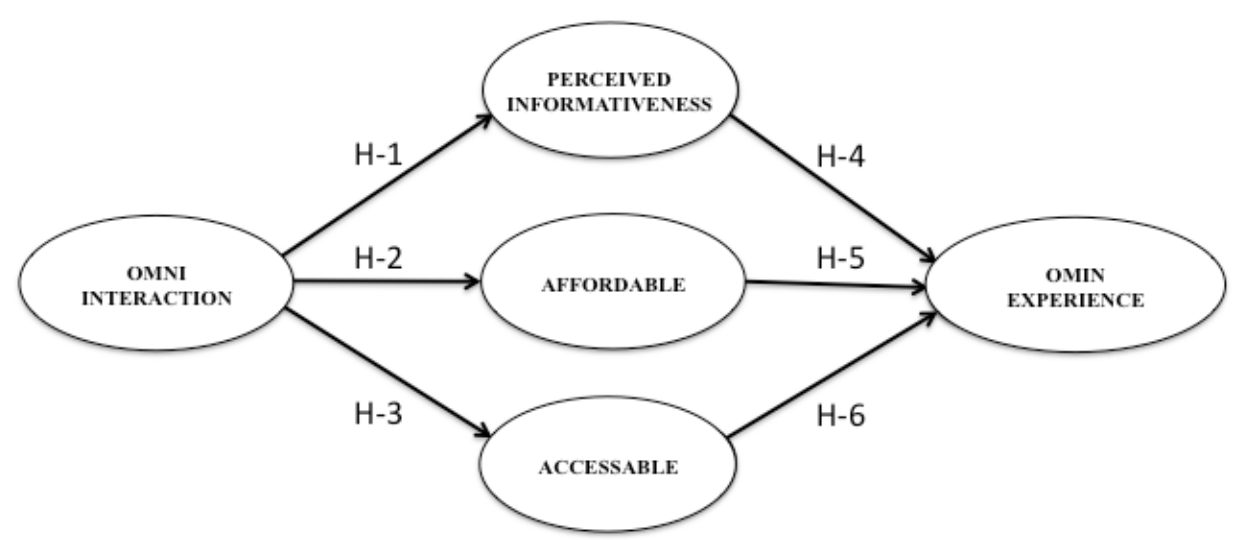

Fig. 1. Research model

This research develops the following research model (Figure 1), H-1 until H-3 showing the relationship between Omni-interaction as an exogenous variable with Perceived Informativeness, Affordable and Accessibility as an intervening variable. H-4 until H-6 showing the relationship between Perceived Informativeness, Affordable and Accessibility as an intervening variable with Omni-experience as an endogenous variable.

\section{Research Methodology}

The questionnaire consisted of two parts. The first part contained statements about retail omni-channel represent the five variables research focused on retail omni-channel consumer (Table 1); respondents were requested to rate their agreement with each item on a four-point Likert scale ranging from 1 (strongly disagree) to 4 (strongly agree). Data was collected through questionnaires distributed in omni-channel consumer from Java island (in line with the results of the APJII survey that the island of Java ranks highest among internet users in Indonesia in 2017: 58\%) using non-probability with accidental sampling method. In all, 138 respondents indicated their recent purchase in last 12 months priors to the collection of the data (October 2019). 
Table 1. Variable, Constructs and items, included in the questions

\begin{tabular}{|c|c|c|c|}
\hline \multirow{2}{*}{$\frac{\text { Variable }}{\text { Omni- Interaction }}$} & \multicolumn{2}{|c|}{ Construct } & \multirow{2}{*}{$\begin{array}{l}\text { Item Measurement } \\
\text { I feel a consistent of product or sales information on } \\
\text { all channels. }\end{array}$} \\
\hline & Information & OI-1 & \\
\hline & Process & OI-2 & I feel a consistent of purchase process on all channels \\
\hline & Data & OI-3 & $\begin{array}{l}\text { I feel a consistent of integrated consumer data on all } \\
\text { channel }\end{array}$ \\
\hline & Logistic & OI-4 & $\begin{array}{l}\text { I feel a consistent of logistics integration is always on- } \\
\text { time }\end{array}$ \\
\hline \multirow[t]{3}{*}{$\begin{array}{l}\text { Perceived } \\
\text { Informativeness }\end{array}$} & $\begin{array}{l}\text { Online } \\
\text { Advertising }\end{array}$ & PI-1 & $\begin{array}{l}\text { I feel online advertising helps me when making a } \\
\text { purchase decision. }\end{array}$ \\
\hline & Social Media & PI-2 & $\begin{array}{l}\text { I feel product reviews from social media helped me } \\
\text { when making a purchasing decision. }\end{array}$ \\
\hline & E-WOM & PI-3 & $\begin{array}{l}\text { I feel product information by electronic word of } \\
\text { mouth / e-WOM is very helpful when making } \\
\text { purchase decisions. }\end{array}$ \\
\hline \multirow[t]{3}{*}{ Affordable } & Quality & AF-1 & $\begin{array}{l}\text { I feel quality is a factor that influences me when } \\
\text { evaluating purchases. }\end{array}$ \\
\hline & Price & AF-2 & $\begin{array}{l}\text { I feel price is a factor that influences me when } \\
\text { evaluating purchases. }\end{array}$ \\
\hline & $\begin{array}{l}\text { Decision } \\
\text { Changes }\end{array}$ & $\mathrm{AF}-3$ & $\begin{array}{l}\text { I feel special offers will affect me when evaluating } \\
\text { purchases. }\end{array}$ \\
\hline \multirow[t]{3}{*}{ Accessibility } & Access & $\mathrm{AC}-1$ & $\begin{array}{l}\text { I feel free to make purchases and take goods anywhere } \\
\text { makes it easy for me to make purchases. }\end{array}$ \\
\hline & Store Loyalty & AC-2 & $\begin{array}{l}\text { I always repeated purchases at the same store that I } \\
\text { have visited before. }\end{array}$ \\
\hline & $\begin{array}{l}\text { Impulsive } \\
\text { Buying }\end{array}$ & $\mathrm{AC}-3$ & $\begin{array}{l}\text { I always do easily, anytime and anywhere for the } \\
\text { Impulse buying. }\end{array}$ \\
\hline \multirow[t]{3}{*}{ Omni-Experience } & Cognitive & OE-1 & $\begin{array}{l}\text { I feel pleasured when easily get the variety of } \\
\text { information on all channels }\end{array}$ \\
\hline & Affective & OE-2 & $\begin{array}{l}\text { I feel satisfied when received good service of purchase } \\
\text { on all channels }\end{array}$ \\
\hline & Conative & OE-3 & $\begin{array}{l}\text { I feel confortable when I have many choices to } \\
\text { purchase on all channels }\end{array}$ \\
\hline
\end{tabular}

The second part of the questionnaire was used to gather socio-demographic information, such as gender, age, employment status, and education. Respondent's characteristic quit similar for male (51\%) and female (49\%), and for productive age quit similar for below 40 Years old, around 31-34\%. Most of respondent are bachelor (78\%) than postgraduate and doctor $(22 \%)$. Most of purchase online with smartphone $(97 \%)$ and shopped online one in a month $(55 \%)$. 


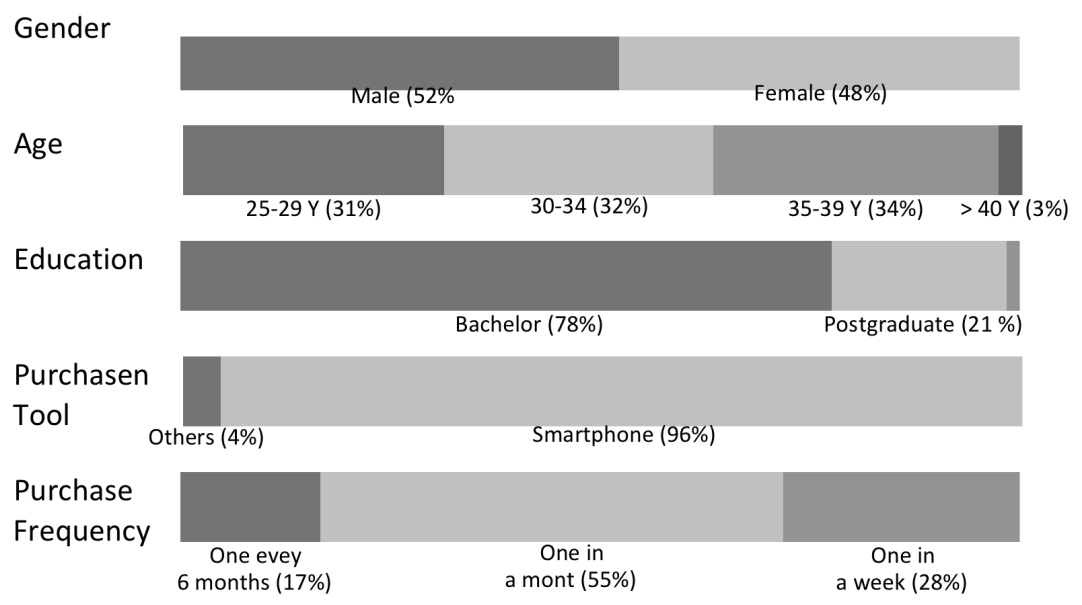

Fig. 2. Respondent Characteristic

\section{Result and Discussions}

The variance-based partial least squares (PLS) path modeling technique was chosen to test the hypotheses (Ringle et al., 2005). PLS path models are defined in terms of inner and outer models (Figure 3). Therefore, this research used SmartPLS 3.0 to test the hypotheses. In addition, the model stability was tested via a bootstrap procedure.

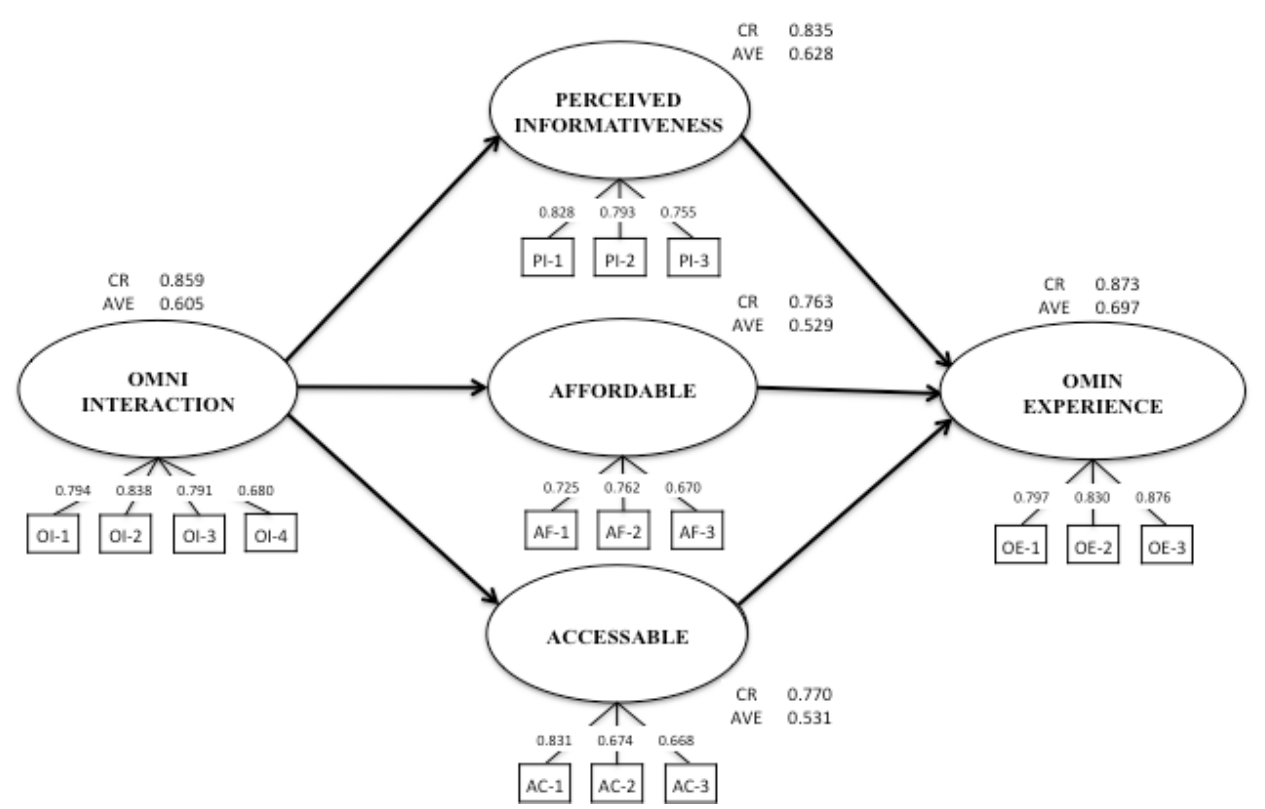

Fig. 3. Smart PLS Result 
The results (Table 2) indicate that all items possess significant, standardized loading factor greater than 0.50 (Chin, 1998; Imam, 2015). The value of Average Variance Extracted (AVE) for all variables had a loading factor greater than 0.50, suggesting they were valid for measuring their constructs and the value of Composite Reliability (CR) greater than 0.7 (Nunnally, 1978), which showed that all variables met the reliability requirements.

Table 2. Results of Validity and Reliability

\begin{tabular}{|c|c|c|c|c|c|c|}
\hline \multicolumn{2}{|l|}{ Items } & \multirow{2}{*}{$\begin{array}{l}\text { Loading } \\
\text { Factor }\end{array}$} & \multirow{6}{*}{$\begin{array}{c}\text { Composite } \\
\text { Reliability } \\
\mathbf{0 . 8 5 9}\end{array}$} & \multirow{6}{*}{$\begin{array}{c}\text { Average } \\
\text { Variance } \\
\text { Extracted (AVE) } \\
\mathbf{0 . 6 0 5}\end{array}$} & \multirow{6}{*}{$\begin{array}{l}\text { Relationship } \\
\\
\text { Significant } \\
\text { Significant } \\
\text { Significant } \\
\text { Significant }\end{array}$} & \multirow{2}{*}{$\begin{array}{c}\text { Measurement } \\
\text { Valid and } \\
\text { Reliable }\end{array}$} \\
\hline Omni-Interaction & & & & & & \\
\hline - Information & OI-1 & 0.794 & & & & \\
\hline - Process & $\mathrm{OI}-2$ & 0.838 & & & & \\
\hline - Data & OI-3 & 0.791 & & & & \\
\hline - Logistic & OI-4 & 0.680 & & & & \\
\hline Perceived Informat & tiveness & & 0.835 & 0.628 & & $\begin{array}{l}\text { Valid and } \\
\text { Reliable }\end{array}$ \\
\hline $\begin{array}{l}\text { - Online } \\
\text { Advertising }\end{array}$ & PI-1 & 0.828 & & & Significant & \\
\hline - Social Media & PI-2 & 0.793 & & & Significant & \\
\hline - E-WOM & PI-3 & 0.755 & & & Significant & \\
\hline Affordable & & & 0.763 & 0.519 & & $\begin{array}{l}\text { Valid and } \\
\text { Reliable }\end{array}$ \\
\hline - Quality & AF-1 & 0.725 & & & Significant & \\
\hline - Price & $\mathrm{AF}-2$ & 0.762 & & & Significant & \\
\hline $\begin{array}{l}\text { - Decision } \\
\text { Changes }\end{array}$ & AF-3 & 0.670 & & & Significant & \\
\hline Accessibility & & & 0.770 & 0.531 & & $\begin{array}{l}\text { Valid and } \\
\text { Reliable }\end{array}$ \\
\hline - Access & $\mathrm{AC}-1$ & 0.831 & & & Significant & \\
\hline - Store Loyalty & AC-2 & 0.674 & & & Significant & \\
\hline $\begin{array}{l}\text { - Impulsive } \\
\text { Buying }\end{array}$ & $\mathrm{AC}-3$ & 0.668 & & & Significant & \\
\hline Omni-Experience & & & 0.873 & 0.697 & & $\begin{array}{l}\text { Valid and } \\
\text { Reliable }\end{array}$ \\
\hline - Cognitive & OE-1 & 0.797 & & & Significant & \\
\hline - Affective & OE-2 & 0.830 & & & Significant & \\
\hline - Conative & OE-3 & 0.876 & & & Significant & \\
\hline
\end{tabular}

Once the measurement model met the elements of validity and reliability, the model was executed using bootstrapping to measure the research model (Figure 4). 


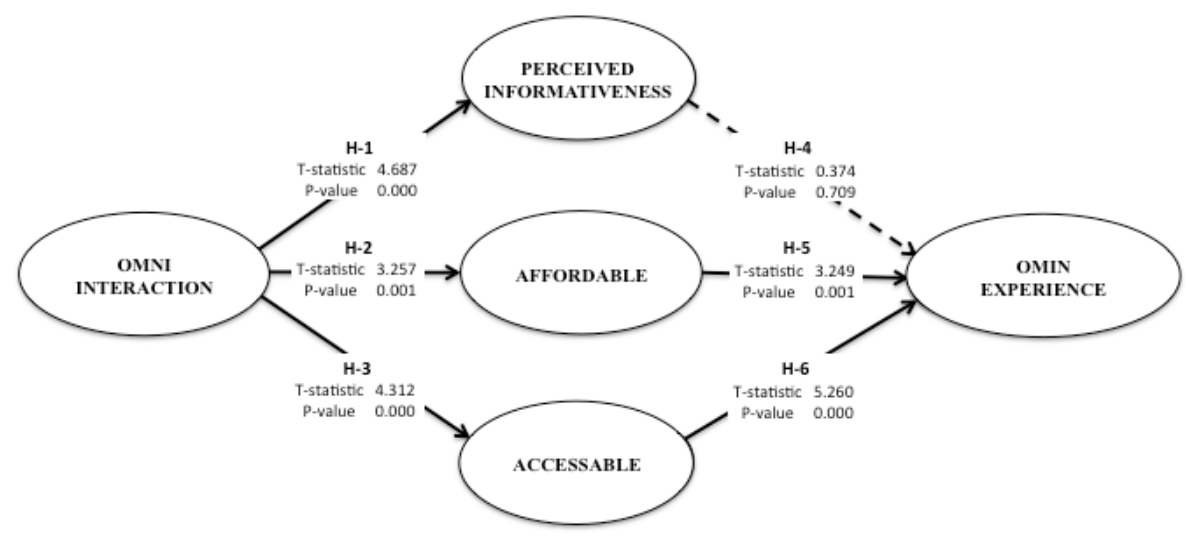

Fig. 4. Smart PLS Bootstrapping Result

The first hypothesis: H1 addressed the relationship between omni-interaction and Perceived Informativeness. As shown in Table 3, the measurements included a T-statistics value is $4.687(>0.196)$ and $\mathrm{P}$-value is $0.000(<0.05)$, indicating omni-interaction has a significant effect on Perceived Informativeness. These findings is in-line with previous research by Oliver (1997), Oliver (1999), Da Silva et al (2006), and Garaus et al. (2015)), which found that the perceived benefits of using online services will positively influence consumer attitudes and intentions.

The second hypothesis: $\mathrm{H} 2$ addressed the relationship between omni-interaction and affordable, the T-statistics value is $3.257(>0.196)$ and P-value is $0.001(<0.05)$, indicating omni-interaction has a significant effect on affordable. This finding is in-line with the previous research by Brown et al. (2002) and Zettelmeyer et al. (2006), internet give consumers the opportunity to be able to choose the best deals and also the opportunity for consumers to engage in cheap price comparisons.

The third hypothesis: H3 addressed the relationship between omni-interaction and accessibility, which T-statistics value of $4.312(>0.196)$ and P-value is $0.000(<0.05)$, indicating omni-interaction has a significant effect on accessibility. Consumers are connected to get access to information and buy anything, anywhere, anytime (Piotrowicz, 2014). The results of this study are in accordance with research by Emma et al. (2016), which states that ease of access is the main interaction of consumers to access purchases or pick up products.

Table 3. Results of Measurement Model Variables

\begin{tabular}{|c|c|c|c|c|}
\hline Hypothesis & $\begin{array}{l}\text { Original } \\
\text { Sample }\end{array}$ & $\begin{array}{c}T \\
\text { Statistics }\end{array}$ & P Values & Result \\
\hline \multirow[t]{2}{*}{ 1. Omni-Interaction $\square$ Perceived Informativeness } & 0.403 & 4.687 & 0.000 & Significant \\
\hline & & & & H1: Accepted \\
\hline \multirow[t]{2}{*}{ 2. Omni-Interaction $\square$ Affordable } & 0.290 & 3.257 & 0.001 & Significant \\
\hline & & & & H2: Accepted \\
\hline \multirow[t]{2}{*}{ 3. Omni-Interaction $\square$ Accessibility } & 0.378 & 4.312 & 0.000 & Significant \\
\hline & & & & H3: Accepted \\
\hline
\end{tabular}




\begin{tabular}{|c|c|c|c|c|}
\hline Hypothesis & $\begin{array}{c}\text { Original } \\
\text { Sample }\end{array}$ & $\underset{\text { Statistics }}{T}$ & P Values & Result \\
\hline \multirow[t]{2}{*}{ 4. Perceived Informativeness $\square$ Omni-Experience } & 0.028 & 0.374 & 0.709 & Not Significant \\
\hline & & & & H4: Rejected \\
\hline \multirow[t]{2}{*}{ 5. Affordable $\square$ Omni-Experience } & 0.264 & 3.249 & 0.001 & Significant \\
\hline & & & & H5: Accepted \\
\hline \multirow[t]{3}{*}{ 6. Accessibility $\square$ Omni-Experience } & 0.453 & 5.260 & 0.000 & Strongly \\
\hline & & & & Significant \\
\hline & & & & H6: Accepted \\
\hline
\end{tabular}

The fourth hypothesis: H4 addressed the relationship between Perceived Informativeness and Omni-experience. As shown in Table 3, the measurements included a T-statistics value is $0.374(<0.196)$ and P-value is $0.709(>0.05)$, indicating Perceived Informativeness has a not significant effect on Omni-Experience. This result confirmed the theory of perceived informativeness, which is more influenced by the type, and content of information, (Soley et al., 1983) and also the consumer demographic (O'Keefe et al., 1981). Consumers cannot touch or smell a product, as might be the case in traditional retail outlets, so the assessment of their purchases must be based on online information (Albaet et al., 1997). Information from other consumers is very helpful in making purchasing decisions because it provides indirect experience (Chatterjee, 2001; Chen et al., 2004). They often seek information from the environment that is considered more credible to determine the benefits of a product (Katherine, 2012)

The fifth hypothesis: H5 addressed the relationship between affordable and omniexperience. As shown in Table 3, the measurements included a T-statistics value is 3.249 ( $>$ $0.196)$ and $\mathrm{P}$-value is $0.001(<0.05)$, indicating affordable has a significant effect on OmniExperience. ArunKumar et al. (2017) states that quality, comfort, and price factors with a pleasant experience are the dominant factors that provide online shopping satisfaction.

The sixth hypothesis: H6 addressed the relationship between accessibility and omniexperience. As shown in Table 3, the measurements included a T-statistics value is 3.249 ( $>$ $0.196)$ and $\mathrm{P}$-value is $0.001(<0.05)$, indicating accessibility has a significant effect on OmniExperience. Research by Emma et al. (2016) also shows that consumers like to use various channels in the buying process, including access to purchase or take products (Fernie et al., 2015).

The hypotheses were supported by the results except H-4: Perceived Informativeness positively not influences Omni-Experience. To determine the effect of omni-interaction on the omni-experience through perceived informativeness, the total effect testing is done through testing the direct effect of exogenous variable to endogenous variable, and indirectly effect between the independent variable and the dependent variable, through mediation variables. Therefore, the total effect is used to see the total prediction effect (direct and indirect effect). 


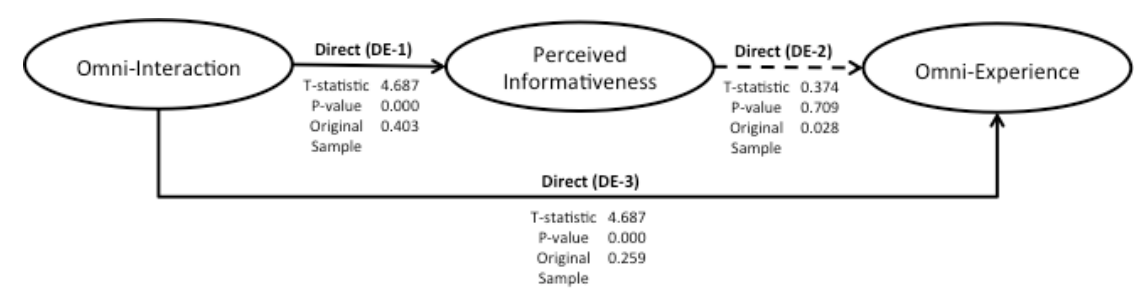

Fig. 5. Path Coefficients for Direct and Indirect through Perceived Informativeness

Figure 5 show the path coefficients of direct effect from original sample value for omniinteraction to perceived informativeness (DE-1: 0.403), perceived informativeness to omniexperience (DE-2: 0.028) and omni-interaction to omni-experience (DE-3: 0,259). From direct effect we can calculate the indirect effect and total effect for omni-interaction to omniexperience via perceived informativeness through formula:

\begin{tabular}{|c|c|c|c|}
\hline Indirect Effect (ID) & $=\mathrm{DE}-1 \times \mathrm{DE}-2$ & Total Effect & $=\mathrm{DE}-3$ \\
\hline 10 & $=0.403 \times 0.028$ & & $=0.2$ \\
\hline 0.011 & $=0.011$ & & $=0.270$ \\
\hline
\end{tabular}

The result of total effect is 0.270 higher than direct effect (DE-3: 0.259) for omniinteraction to omni-experience via perceived informativeness, indicating omni-interaction have a significant effect on omni-experience via perceived informativeness compare than direct effect.

\section{Conclusion}

Retail world has given rise to a new phenomenon known as omni-channel retailing (Herhausen et al, 2015). The dominant characteristic of the omni-channel is that the strategy is centered on the consumer and the consumer's shopping experience, with a view to offering the shopper a holistic experience (Gupta et al., 2004).

This research comprehensively investigates relation between omni-interaction and omniexperience mediating by Perceived Informativeness, Affordable and Accessibility. The result of the research, the hypotheses was supported with the significant and strengthens the relation omni-interaction and omni-experience mediating by Perceived Informativeness, Affordable and Accessibility. Perceived Informativeness required more attention to influence the Omniexperience, consumer often to seek information from the environment that is considered more credible to determine the benefits of a product (Taken, 2012). Understands consumers and their experiences (Puccinelli et al., 2009), create comprehensive process of omni-channel retailing that makes it easy for consumers and retailer (Lazaris et al., 2014; McCormick et al., 2014; Rigby, 2011; Rigby, 2014; Carvalho et al., 2014).

The limitation of this research is that the respondent was sampled from consumer of online retailers Indonesia. The omni-channel might have different effects in different countries. It would be interesting to replicate this study in another demography or country to compare the results. 


\section{References}

[1] Agnieszka Kurczewska, Paula Kyrö, Krista Lagus, Oskar Kohonen, and Tiina LindhKnuutila (2017),"The interplay between cognitive, conative, and affective constructs along the entrepreneurial learning process" Education + Training (C) Emerald Publishing Limited

[2] Ailawadi, Kusum L.; Scott A. Neslin; and Karen Gedenk (2001), "Pursuing the ValueConscious Consumer: Store Brands Versus National Brand Promotions.” Journal of Marketing.

[3] Angel, T.O.S. (2014), "A Study of Omni-channel Retailing: The Impact of Integration Quality on Omni-channel Satisfaction and Omni-Channel Loyalty in Apparel Retail Business." The Hongkong Polytechnic University.

[4] Arun Kumar SivaKumar and Abirami Gunasekaran (2017), "An Empirical Study on the Factors Affecting Online Shopping Behavior of Millennial Consumers," Journal of Internet Commerce.

[5] Aubrey, C. and Judge, D. (2012), "Re-imagine Retail: Why Store Innovation is Key to a Brand's Growth in the New Normal, Digitally-Connected and Transparent World," Journal of Brand Strategy.

[6] Blackwell, R.D.; Miniard, P.W.; and Engel, J.F. (2012), "Consumer Behavior." Cengage Learning Asia Pte Ltd, Singapore.

[7] Bob Gilbreath (2010), "The Next Evolution of Marketing," The McGraw Hill companies.

[8] Brown J.E. and Tuten T.L. (2009), "Virtual Social Identity and Consumer Behavior," New York: Society fo Consumer Psychology.

[9] Brown, J. R. and Goolsbee, A. (2002), "Does the internet Make Markets More Competitive? Evidence from the Life Insurance Industry." Journal Politic Economy.

[10] Brynjolfsson, E.; Hu, Y. J.; and Rahman, M. S. (2013), "Competing in the Age of Omni-channel Retailing." MIT Sloan Management.

[11] Burke, R. R. (2002), "Technology and the Customer Interface: What Consumers Want in the Physical and Virtual Store", Journal of the Academy of Marketing Science

[12] Carvalho, J.L.G. and Campomar, M.C. (2014), "Multichannel at Retail and Omni Channel: Challenges for Marketing and Logistic." Business and Management Review.

[13] Chin, W. W. (1998), "The Partial Least Squares Approach to Structural Equation Modeling," Modern Methods for Business Research: Methodology for Business and Management.

[14] Chopra, S., (2016), "How Omni-Channel can be the Future of Retailing", Decision, Vol. 43

[15] Cook, G. (2014), "Customer Experience in the Omni-Channel World and the Challenges and Opportunities this Presents." Journal of Direct, Data and Digital Marketing Practice.

[16] Dabija, Dan-cristian, (2016), "Investigating Shopping Experience and Fulfillment in Omnichannel Retailing: A Proposed Comparative Study in Romanian and UK of Generation Y Consumers," Research Gate

[17] Deutsch, M. and Gerrard, H.B (1955), "A Study of Normative and Informational Social Influence Upon Individual Judgment," Journal of Abnormal and Social Psychology.

[18] Dijk, G. van, Laing, A., and Minocha, S. (2005), "Consumer Behaviour in MultiChannel Retail Environments: Consumer movement between online and offline channels", in 5th American Marketing Association Academy of Marketing

[19] Egol, M. Rajagopalan, A. and Sayer, B. (2012), "E-commerce and Consumer Goods: A 
strategy for Omni-Channel Success." Pricewaterhouse Coopers / PwC.

[20] Emma Juaneda-Ayensa; Ana Mosquera and Yolanda Sierra Murillo (2016), "Omnichannel Customer Behavior: Key Drivers of Technology Acceptance and Use and Their Effects on Purchase Intention." Frontiers in Psychology.

[21] Fernie, John; Fernie, Suzanne and Christopher Moore (2015), "Principles of Retailing", Routledge, London

[22] Flor Madrigal Moreno; Jaime Gil Lafuente; Fernando Ávila Carreón; and Salvador Madrigal Moreno (2017), "The Characterization of the Millennials and Their Buying Behavior." International Journal of Marketing Studies.

[23] Frazer, M. and Stiehler, E. (2014), "Omni-channel Retailing: The Merging of the Daring and Luring Environment." Global Conference on Business and Finance Proceedings.

[24] Gerritsen, B.H.M., Soilen, K.S.S., de Visser P.B., Hoogreed, P.J.M., Hulst, K., Janssen, M.L., Horselenberg, L., Van Dijk, R.R. and Cosenheim, E. (2014), "Social Media Coming to the Mall: A Corss-Channel Response," Product Development in the SocioSphere, Springer International Publishing Switzerland

[25] Goldsmith R.R.E. and Horowitz D. (2006), "Measuring Motivations for Online Opinion Seeking," Journal of Interactive Advertising.

[26] Gupta, S.; Lehmann, D. R. and Stuart, J. A. (2004), "Valuing Customers." Journal Marketing.

[27] Herhausen, Dennis, Jochen Binder, Marcus Schoegel, and Andreas Herrman (2015), "Integrating Bricks with Clicks: Retailer-Level and Channel-Level Outcomes of Online-Offline Channel Integration," Journal of Retailing

[28] Imam Ghozali and Hengky Latan (2015), "Partial Least Squares, Konsep, Teknik dan Aplikasi Menggunakan Program SmartPLS 3.0," Badan Penerbit Undip

[29] Ira Kaufma and Chris Horton (2015), "Digital Marketing, Integrated Strategy and Tactics with Values", Routledge

[30] Jonah Berger and Raghuram Iyengar (2013), "Communication Channels and Word of Mouth: How the Medium Shapes the Message," Journal of Consumer Research.

[31] Juan Carlos Bustamante and Natalia Rubio, (2017) "Measuring customer experience in physical retail environments", Journal of Service Management, Vol.

[32] Karen Whitehall King; Leonard N. Reid; Spencer F. Tinkham and James Pokrywczynski (1987), "The Perceived Informativeness of National and Retail Advertising," Journal of Current Issues and Research in Advertising.

[33] Katherine Taken Smith (2012), "Longitudinal Study of Digital Marketing Strategies Targeting Millennials." Emerald Group Publishing Limited.

[34] Kollmann, Tobias; Andreas Kuckertz; and Ina Kayser, (2012), Cannibalization or synergy? consumers' channel selection in online-offline multichannel systems, Journal of Retailing and Consumer Services

[35] Kotler, P.; Hermawan Kartajaya; and Iwan Setiawan (2016), "Marketing 4.0: Moving from Traditional to Digital." Wiley.

[36] Küster, I., Vila, N., and Canales, P. (2016), "How does the online service level influence consumers purchase intentions before a transaction? A formative approach," European Journal of Management and Business Economics

[37] Laudon, Kenneth C. and Traver, Carol G. (2015). "E-Commerce 2015: Business, Technology, Society (11 Edition)." Pearson Education, Londan

[38] Lazaris, C. and Vrechopoulos, A. (2014), "From Multichannel to "Omni-channel" Retailing: Review of the Literature and Calls for Research." 2nd International 
Conference on Contemporary Marketing Issues (ICCMI) Athens.

[39] Lee, M. C. (2009), "Factors influencing the adoption of internet banking: An integration of TAM and TPB with perceived risk and perceived benefit." Electronic Commerce Research and Applications.

[40] Lichtenstein, Donald R.; Richard G. Netemeyer; and Scot Burton (1995), "Assessing the Domain Specificity of Deal Proneness: A Field Study." Journal of Consumer Research.

[41] Lin A. and Foster J. (2013), " Electronic World of Mouth (e-WOM) and Its influence on Book Purchasing Decisions," Consumer Information System and Relationship Management.

[42] Lissitsa Sabina and Ofrit Kol (2016), "Generation X vs. Generation Y - A Decade of Daring Shopping." Journal of Retailing and Consumer Services.

[43] Man Yee Cheung; Chuan Luo; Choon Ling Sia and Huaping Chen (2009), "Credibility of Electronic Word-of-Mouth: Informational and Normative Determinants of On-Line Consumer Recommendations," International Journal of Electronic Commerce.

[44] Marshall Fisher, Vishal Gaur, and Herb Kleinberger (2017), "Curing the Addiction to Growth," Harvard business review

[45] McCormick, H.; Cartwright, J.; Perry, P.; Barnes, L.; Lynch, S.; and Ball, G. (2014), "Fashion Retailing - Past, Present and Future." Textile Progress.

[46] Mochon, D., Norton, M.I. and Ariely, D. (2012), 'Bolstering and Restoring Feelings of Competence via the IKEA Effect', International Journal of Research in Marketing, Vol. 29

[47] Mohammed, Rafi; Robert J. Fisher; Bernard J. Jaworski; and Aileen Cahill (2003), "Internet Marketing: Building Advantage in a Network Economy." McGraw Hill Companies.

[48] Neslin, S. A.; Jerath, K.; Bodapati, A.; Bradlow, E. T.; Deighton, J. and Gensler, S. (2014), "The Interrelationships Between Brand and Channel Choice." Marketing Letter, A Journal of Research in Marketing.

[49] Nunnally, J. (1978), "Psychometric theory," New York: McGraw-Hill

[50] O'Keefe, Garrett J.; Nash, Kathaleen; and Liu, Jenny (1981), "The Perceived Utility of Advertising," Journalism Quarterly.

[51] Otto, J. R., and Chung, Q. B. (2000), “A Framework for Cyber-Enhanced Retailing: Integrating E-Commerce Retailing with Brick-and-Mortar Retailing”, Electronic Markets

[52] Piotrowicz, W. and Cuthbertson, R. (2014), "Introduction to the Special Issue Information Technology in Retail: Toward Omni-channel Retailing." International Journal Electronic Commercial.

[53] Rajeev Batra and Kevin Lane Keller (2016), "Integrating Marketing Communications: New Findings, New Lessons, and New Ideas," Journal of Marketing.

[54] Ratneshwar, S., David Mick and Cythia Huffman (2000), "The Why of Con- sumption: Contemporary Perspectives on Consumer Motives, Goals and Desires," New York: Routledge.

[55] Rayport J.F. and Jaworski B.J. (2003), "Introduction to E-Commerce (2nd edition)." McGraw Hill

[56] Rigby, Darrell K (2011), "The Future of Shopping." Harvard Business Review.

[57] Rigby, Darrell K (2014), "Digital-Physical Mashups." Harvard Business Review.

[58] Ringle, C. M., Wende, S., and Will, A. (2005). SmartPLS 2.0 (beta). Hamburg: www.smartpls.de. 
[59] Saini, Yvonne K. and John G. Lynch Jr. (2016), "The Effects of the Daring and Luring Purchase Environment on Consumer Choice of Familiar and Unfamiliar Brands." International Jounal of Research in Marketing.

[60] Sam K.M. and Chatwin C. (2015), "Online Consumer Decision-Making Styles for Enhanced Understanding of Macau Daring Consumer Behavior." Asia Pacific Management Review.

[61] Schiffman L.G. and Wisenblitt J.L. (2015), "Consumer Behavior, 11th Edition," London: Pearson Education Ltd.

[62] Silverman, George (2011), "The secrets of Word of Mouth Marketing: How to Trigger Exponential Sales Trough Runaway Woth of Mouth, 2nd Edition," New York: Amacom.

[63] Siobhan-Hatton, J. and Min, T., (2015), 'Case Analysis of the Do-It-Yourself Industry', Asia Pacific Journal of Marketing and Logistics, Vol. 27

[64] Smith, K. T. (2012), "Longitudinal Study of Digital Marketing Strategies Targeting Millennials," Journal of Consumer Marketing.

[65] Soley, Lawrence C. and Reid, Leonard N. (1983), "Is the Perception of Informativeness Deter- mined by the Quantity or the Type of Information in Advertising?" Current issues and Research in Advertising.

[66] Steeenkamp, Jan-Benedict E.M. and Alberto Maydeu-Olivares (2015), "Stability and Change in Consumer Traits: Evidence from a 12 Year Longitudinal Study, 2002-2013." Journal of Marketing Research.

[67] Steenkamp, Jan-Benedict E.M. (1989), "Product Quality." Van Gorcum.

[68] Toufaily E.; Souoiden N. and Ladhari R. (2013), "Consumer trust toward retail websites: comparison between pure click and click and brick retailers," Journal of Retailing and Consumer Services.

[69] Verhoef, P. C.; Kannan, P. K. and Inman, J. J. (2015), "From Multi-Channel Retailing to Omni-Channel Retailing: Introduction to the Special Issue on Multi-Channel Retailing." Journal Retail.

[70] Verhoef, Peter C., Katherine N. Lemon, A. Parasuraman, Anne Roggeveen, Leonard A. Schlesinger and Michael Tsiros (2009), Customer Experience: determinants, dynamics and management strategies, Journal of Retailing.

[71] Yee, P.M. and Heutger, M. (2015), "Omni-Channel Logistics. A DHL Perspective on Implications and Use Cases for the Logistics Industry", Troisdorf, Germany: DHL Customer Solutions \& Innovation, Troisdorf, Germany

[72] Yoran Jerry Wind (2008), "A plan to Invent the Marketing We Need Today," MIT Sloan Management Review.

[73] Yorgo Pasadeos (1990), "Perceived Informativeness of and Irritation with Local Advertising," Journalism and Mass Communication Quarterly.

[74] Zettelmeyer, F.; Morton, F. S. and Silva-Risso, J. (2006), "How the Internet Lowers Prices: Evidence from Matched Survey and Automobile Transaction Data." Journal Marketing.

[75] Zhang, J., Farris, P.W., Irvin, J.W., Kushwaha, T., Steenburgh, T.J., and Weitz, B.A. (2010), "Crafting integrated Multichannel Retailing strategies," Journal Interact. 